TEME, г. XLV, бр. 1, јануар - март 2021, стр. 383-402

Прегледни рад https://doi.org/10.22190/TEME181222021P

Примљено: 22. 12. 2018.

UDK 94(497.11)"1868/1873"

Ревидирана верзија: 22. 1. 2021.

Одобрено за штампу: 26. 2. 2021.

\title{
ОКУПЉАЊЕ ЛИБЕРАЛА ПОД ВОЪСТВОМ ЈОВАНА РИСТИЋА ОД 1868. ДО 1873. ГОДИНЕ
}

\author{
Мирослав Пешић*
}

Универзитет у Нишу, Филозофски факултет, Ниш, Србија

\begin{abstract}
Апстракт
У раду су приказани напори Намесништва, а нарочито Јована Ристића, да током четворогодишњег мандата, служећи се притом разним средствима, окупи што већи број либерала око себе. Већина либерала је прихватила намеснички режим, у нади да ће ублажити полицијско-бирократски режим увођењем одређених реформи. Други намесник Јован Ристић је заједно са Блазнавцем, првим намесником, користећи све полуге власти, окупљао око себе политичке присталице, не искључујући ни либерале са Светоандрејске скупштине, иако га они никада нису доживљавали као свог истомишљеника. Упркос чињеници да је стајао уз Илију Гарашанина, противника либерала, Ристић је успео да се наметне као њихов предводник. Овај државник отпочео је владавину покретом либерала, а да сам није много веровао у идеје либерализма.
\end{abstract}

Кључне речи: Јован Ристић, либерали, Намесништво, Миливоје Петровић Блазнавац, Устав из 1869. године.

\section{THE GATHERING OF THE LIBERALS UNDER THE LEADERSHIP OF JOVAN RISTIC FROM 1868 TO 1873}

\section{Abstract}

This paper shows the efforts of the Governorship, and especially Jovan Ristic's efforts during the four-year mandate, to gather a large number of Liberals around him using various means. Most of the Liberals accepted the regime of the Governorship hoping that it would soften the political-bureaucratic regime by introducing certain reforms. The second governor, Jovan Ristic, together with the first one, Blaznavac, gathered political supporters around him using all levers of power, not even excluding the liberals of St. Andrea's assembly, even though they had never seen him as their political ally. Despite the fact that he stood with an enemy of the liberals, Ilija Garasanin, Ristic managed to impose himself as their leader. This statesman started

\footnotetext{
* Аутор за кореспонденцију: Мирослав Пешић, Филозофски факултет у Нишу, Ћирила и Методија 2, 18000 Ниш, Србија, miroslav.pesic@ filfak.ni.ac.rs
} 
the reign with the movement of liberals, although he did not believe in the ideas of liberalism himself.

Key words: Jovan Ristic, liberals, the governorship, Milivoje Petrovic Blaznavac, The Constitution of 1869 .

УВОД

После убиства кнеза Михаила Обреновића 10. јуна 1868. у Кошутњаку, образовано је привремено намесништво које су чинили Јован Мариновић и његов лични пријатељ Илија Гарашанин. Привремену владу образовао је Милан Петронијевић. Избор новог кнеза Милана Обреновића, који је допутовао у Београд 23. јуна 1868. године, требало је да обави Велика народна скупштина 2. јула 1868. Будући да га је војска Београдског гарнизона, предвођена министром војним Миливојем Блазнавцем, изабрала за наследног кнеза 12. јуна, Скупштина је питање попуњавања упражњеног престола решила тако што је утврдила наследно право Обреновића на престо. Том приликом су изабрани намесници малолетном владару: Миливоје Петровић Блазнавац, Јован Ристић и Јован Гавриловић. На тај начин, одлука Народног представништва била је прејудицирана, а Блазнавчева улога постала је „претежнија над значајним политичким личностима у земљи" (Рајић, 2015, стр. 67). Милан Обреновић је миропомазан у Саборној цркви у Београду 5. јула, а султанов берат којим је признат за српског кнеза с наследним правом прочитан је две недеље касније у двору. То је био последњи султанов берат издат српским владарима. Тиме је враћено право наследства престола према одредбама из 1830. године (Љушић, 2008, стр. 158). Као министар војни (1865$1868)$, Блазнавац је располагао кључном полугом власти у тренутку убиства кнеза Михаила. Војску је искористио да онемогући Илију Гарашанина, те да се војним ударом домогне власти и себе постави за кључног намесника. Две недеље после атентата у Топчидеру нико у земљи није помињао Илију Гарашанина као кандидата за намесника. Блазнавац је успео у својој намери да потисне свог бившег шефа иако је он као изузетно популарна личност у земљи испрва сматран за пожељног члана Намесништва. По свему судећи, Блазнавац је дошао у први план, јер је обећао аустријском конзулу Калају да ће радити на продубљивању пријатељких односа са Аустроугарском монархијом. У Бечу се сматрало да је Ристић пријатељ Блазнавца и да ће прихватити његову спољну политику. Јован Гавриловић, као трећа личност у Намесништву, готово да се и не помиње (Рајић, 2015, стр. 72-73). Руски конзул у Београду Шишкин био је незадовољан развојем догађаја, јер је пропао његов план да се за намеснике изаберу Гарашанин и Јован Мариновић. Сматрао је да је Блазнавац преузео сву власт у своје руке, али је истицао да је потребно да се ради 
на превазилажењу унутрашње напетости, коју би Аустрија могла искористити за привремену окупацију Кнежевине. Шишкин се питао да ли би било боље да Русија призна „диктатуру Блазнавца” ако би то довело до смиривања страсти у земљи. Он даље наводи:

\begin{abstract}
„Ако Срби нису били способни да опросте кнезу Михаилу његове мање недостатке, који су се искупљивали његовим патриотизмом и великодушношћу, ако су допустили да га убију као пса, нека буду кажњени за то самовлашћем и диктатуром Блазнавца. Они су то потпуно заслужили" (Леовац, 2015, стр. 293).
\end{abstract}

Када је изабран на место намесника, Ристић је имао 37 година, те се на том месту нашао пре многих других истакнутих политичара тога времена, који су у својим каријерама обављали много значајније државне функције. Будући да је био припадник млађе генерације политичара, да је иза себе имао значајније дипломатске успехе, те да је намеравао да спроведе извесне реформе, то је био довољан разлог да либерална интелигенција подржи Ристића. Подршка интелигенције утицала је на Блазнавца да за свог партнера у Намесништву узме Јована Ристића. Без обзира на то што је тек 1881. године након оснивања Народно-либералне странке формално постао вођа либерала, Јован Ристић се у пракси на тој позицији нашао 1868. године. За време Другог намесништва дошло је до процеса спајања умерених либерала и светоандрејаца и на тај начин су постављени темељи касније основане Либералне странке. Иако до краја нису били задовољни реформама које је донео Устав из 1869. године, чији је творац Јован Ристић и који је био у складу са његовом политиком умереног либерализма, либерали су се масовно окупљали око Ристића и Намесништва. У периоду другог намесништва, Ристићу се указала прилика да око себе окупи либералну интелигенцију и постане главни идеолог либерала. Свој положај вође међу либералима Јован Ристић је успео да још више учврсти током седамдесетих година 19. века (Радовић, 2013, стр. 205-206).

\title{
ЈОВАН РИСТИЋ И ЛИБЕРАЛИ ЗА ВРЕМЕ НАМЕСНИШТВА (1868-1872)
}

Након Топчидерске катастрофе 1868. године, либерали су били упућени на сарадњу са намесничким режимом. Прво, он им је гарантовао заштиту од даљих прогона полиције, јер су били оптуживани да су учествовали у завери против владара; друго, пристао је да спроведе реформе. Јован Ристић, који је за време Светоандрејске скупштине 1858. године заступао умерени либерализам, сматрао је да је полицијско-бирократски режим кнеза Михаила постао толико непо- 
пуларан да неће опстати уколико се не ублажи. Намеравао је да донесе нови устав, јер му је претходни из 1838. године сметао зато што је био конзервативан и наметнут од Турске. Неслагање са постојећом политиком кнеза Михаила обезбедило му је извесну популарност међу слободоумном интелигенцијом, иако га убеђени либерали Милован Јанковић, Владимир Јовановић и Јеврем Грујић нису доживљавали као свог истомишљеника (Бешлин, 2005, стр. 650). Почетком 60их година 19. века учињен је први корак у правцу формирања новог језгра либерала. Радивоје Милојковић је женидбом са Милевом ${ }^{1}$, ћерком Хаџи Томе, постао пашеног Јовану Ристићу. После завршених студија вратио се у Србију 1859. године и приближио се светоандрејцима, посебно Јеврему Грујићу и Стевчи Михаиловићу. Светоандрејским либералима задат је велики ударац када је Милојковић прешао на Ристићеву страну, иако је он и даље говорио да припада њиховој политичкој опцији (Радовић, 2013, стр. 197). На политичкој сцени Србије, Ристић је доспео у први план после повратка из Цариграда, где се као српски дипломатски представник нарочито истакао у раду на добијању градова. После повратка у Београд саветовао је кнезу да изведе одређене реформе зарад смиривања унутрашње напетости у земљи. Предочио је кнезу да Србија не би смела да буде подељена, јер не поседује у довољној мери интелектуални капацитет, те да би због тога кнез требало да се окружи интелигенцијом, која се налазила код Владимира Јовановића. Упоредо са тим, Ристић је напомињао да не жели да буде у истом министарству са конзервативцима - Рајком Лешјанином, Костом Цукићем и Николом Христићем. Уместо њих, предлагао је Радивоја Милојковића, Стевчу Михаиловића и Панту Јовановића. Од кнеза је захтевао да у Влади остане министар војни Миливоје Блазнавац. Чињеница да је Ристић предложио кнезу да Стевча Михаиловић образује владу, а не код либерала озлоглашени Никола Христић - оставила је веома повољан утисак код либералне опозиције. Ристић се тада први пут јавно сврстао уз либерале. У том тренутку либерална интелигенција је све више почела да гледа на Ристића као на свог предводника (Радовић, 2013, стр. 202-204).

Ристићу је била добро позната чињеница да је слободоумна интелигенција окупљена око либерала, који су били главни противници политике кнеза Михаила. Обећавајући увођење одређених реформи у земљу, намеравао је да умеренији део либерала привуче на

1 „Те године у месецу септемвру 3. или 4. дана испросим кћер Хаџи Томе, трговца на Сави у Београду, по имену Милеву; и 22. октомвра те 1861. године венчам се с њом. Милева се родила, као што ми казива после таст, 1844. године у месецу септемвру, и тако је била у 18. године када смо се венчали" (Вулетић, Трговчевић, стр. 2003, 81-82). 
своју страну. Иако су се прве партијске клице појавиле за време Светоандрејске скупштине 1858. године, када су се формирале две политичке групације - конзервативци и либерали, тек са намесничким режимом (1868-1872) отпочиње прави политичко-партијски живот у Србији. Доношењем Устава из 1869. године, који је делимично задовољио либерале, Ристић је вештим маневрисањем успео да већи део либерала веже за намеснички режим (Чубриловић, 1958, стр. 323358). Један анонимни аутор, вероватно касније радикал, наводи „да су после 1868. године либералци из забуне и страха, изгубили базис свог становишта, напустили принцип своје опозиције и здружили се са властољубивим Блазнавцем и Ристићем да обману народ" (AC, Вљ-3). Према мишљењу Јаше Продановића, Устав из 1869. године, чији је главни творац Јован Ристић, представљао је програм либерала окупљених око њега. По свему судећи, конзервативне и „умерењачке" погледе, који су доминирали у Уставу из 1869. године, Ристић никада није напустио. Он је говорио: „Ми смо елементи реда идући средином пута видимо и десно и лево поред себе само крајности, а крајностима никада не припада будућност. Либерализам подјемчава слободу с редом, а слобода је с редом неминовни услов друштвеног живота" (Рајић, 1999, стр. 42).

Уставом из 1869. године је у Србију уведен представнички систем, тј. овим уставом је Народна скупштина добила удео у законодавној власти. Скупштина је била састављена од изабраних народних посланика и оних које је кнез постављао. Устав је прописао обичну скупштину и Велику народну скупштину. Посланици су се бирали по варошима на непосредним изборима, а по срезовима на посредним изборима преко повереника. На свака три изабрана посланика кнез је имао право да постави по једног. За посланика је могао бити изабран онај ко је напунио тридесет година живота и ко је плаћао држави порез од најмање шест талира годишње на имање, рад или приход. Адвокати и чиновници нису могли бити народни, већ кнежеви посланици, док је војницима стајаће војске било забрањено да бирају и да буду бирани. Највиши правни акт није успоставио равнотежу снага између Народне скупштине и кнеза, као другог законодавног чиниоца, јер је омогућио кнезу надмоћнији положај у законодавној власти.

Законодавна иницијатива припала је кнезу, а не Народној скупштини. Скупштина је могла само да изјављује жеље да се одређени закон донесе или промени, док је кнез предлагао законе. Нови устав онемогућио је посланике да о закону расправљају у појединостима, тј. нису имали право подношења амандмана на предложени закон. Скупштина је морала или да прихвати или да одбаци предлог закона у целини. Кнез је могао да издаје привремене законе у случају да је безбедност земље доведена у питање и они су важили све док је трајало ванредно стање у 
земљи. Систем избора који је завео Устав из 1869. године није давао довољно јемства за слободу избора, јер је гласање било јавно. Полиција је могла да се меша у изборе, нарочито по срезовима, где су се они вршили преко повереника (Јовановић, стр. 1990а, 29-30). Ако скупштина не би усвојила буџет за нову годину, влада је имала право да пренесе стари буџет за следећу годину. Дакле, буџетско право није припадало скупштини, већ влади. Нови устав је завео представнички систем без парламентарне владавине, јер министри нису били народни посланици и није постојала политичка одговорност министара, већ само кривична. Они нису одговарали скупштини, него кнезу (Љушић, 2010, стр. 96). Министре је постављао и отпуштао кнез, они су у ствари били људи од поверења кнеза, а не скупштине. Слободан Јовановић закључује да „политичка одговорност министара, која чини суштину парламентарног режима, није постојала по Уставу из 1869. године" (Јовановић, 1990б, стр. 74-75). Обавезно одржавање Скупштине и њено учешће у доношењу закона биле су главне тековине Устава из 1869. године. Околност да се Скупштина састајала сваке године, а избори за њу обављали сваке треће године - допринела је интензивирању политичког живота у земљи, стварајући услове да у Скупштину уђу напреднији слојеви друштва, посланици који су допринели јачању политичко-страначких борби у земљи (Јанковић, 1997, стр. 129). У Скупштини, која је по Уставу добила ограничену законодавну власт, посланици су се делили на владине присталице Ристића и Блазнавца, са једне стране, и опозиционе, који су били малобројни, са друге стране. ${ }^{2}$

Одређени број посланика није био задовољан владиним предлогом Устава. Тако је, на пример, посланик из Смедерева Мијаило Стајковац критиковао поједине одредбе Устава, истичући да овим уставом „не добија народ ништа”. Пошто Скупштина није добила право законодавне иницијативе, као ни искључиво буџетско право, Стајковац је захтевао да влада измени предлог Устава „којим ће се признати народу решавајући глас у потпуноме законодавству" (АСАНУ, JP, VI/4, бp. 48).

Намесничким уставом, који је био „скројен” у складу са Ристићевим либерализмом, нису били задовољни и истакнути либерали Јеврем Грујић, Владимир Јовановић, Алимпије Васиљевић, Стојан

\footnotetext{
2 У својим Успоменама Аврам Петровић, дугогодишњи начелник Министарства привреде, сећајући се периода владавине намесника, записао је: „Дотле код нас нису постојале организоване партије. Постојале су само две групе две партије: једна владина, која се називала либералном и друга: опозициона, у коју су улазили сви опозиционири:конзервативци и сви слободнији људи од којих су неке називали комунцима, социјалистима, републиканцима. Тако је тада било и посланика који су дотле били само опозиционари а нису били опредељени шта су" (Петровић, 1988, стр. 89).
} 
Бошковић и Милован Јанковић. За време избора за уставотворну скупштину, власт је чинила све не би ли онемогућила избор Јовановића и Јанковића. Успела је да спречи да Бошковић и Васиљевић буду изабрани за секретаре скупштине. Међутим, либерали нису били прогањани као у време владавине кнеза Михаила и донели су одлуку да сарађују са намесничким режимом. Без обзира на бројне недостатке, за њих је Устав донет у Србији без мешања Порте омогућавао већи степен развоја грађанских слобода него претходни. Истини за вољу, многи истакнути либерали руководили су се и личним разлозима када су одлучили да се одрекну многих ранијих захтева за либералнодемократски преображај земље. Због вишегодишње опозиције режиму, били су изложени разним врстама напада, а Намесништво им је давало значајне државне функције. Тако је, на пример, Димитрије Матић једно време био на челу Министарства спољних послова, а затим је постао министар просвете, посветивши се реформаторском раду у области образовања. Либерали се поново окупљају око Српског ученог друштва, из кога су уклоњени за време режима кнеза Михаила. Јеврем Грујић се почетком 1869. године обратио Радивоју Милојковићу да му помогне да се врати у државну службу. Милојковић, који је био у добрим односима са Јованом Ристићем, помогао је Грујићу и он је постављен за посланика у Цариграду. Стојан Бошковић је постао секретар Министарства спољних послова, Јован Илић је заузео ресор Министарства правде. Место предавача Филозофије и Логике на Великој школи добио је Алимпије Васиљевић. Убрзо је постао редовни професор (Бешлин, 2005, стр. 662-663).

За време кнеза Михаила, либерали су били искључиви, тј. тражили су све или ништа, док су за време Намесништва дошли на идеју „да је бољи и умерени либерализам намеснички него никакав либерализам" (Јовановић, 1990б, стр. 132). Ристић је вође светоандрејаца, међу којима су се посебно истицали Јеврем Грујић и Милован Јанковић, више доживљавао као конкуренте, а мање као политичке противнике. За разлику од њих, Ристић је захваљујући родбинским везама успео да напредује у државној служби. Потребно је указати на чињеницу да су они припадали истој генерацији, коју су образовали исти догађаји и која је имала сличан пут развоја. Као припадници Дружине младежи српске, присуствовали су Мајској скупштини 1848. године, на којој је проглашена српска Војводина, образовали се на истим универзитетским центрима. Анализирајући два Ристићева списа из тог периода - Законитост и Реформе у Србији, долазимо до закључка да је делио исте идеја као и светоандрејски либерали. Истицао је да је неопходно уредити Народну скупштину, увести министарску одговорност, слободу штампе, независност и непокретност судија (Радовић, 2013, стр. 197-198). Његове критике старих политичких установа Србије, које је створио Устав из 1838. године, 
у практичном смислу речи су још тада отвориле уставно питање, иако је оно дошло на ред тек 1869. године (Симеуновић, 2003, стр. 229). У чему се онда састојала разлика између њих? Разлику треба потражити у мери и времену, односно „у апликацији начела. Између великих и умерених либералаца зближење је природно, јер им је начелна цељ једна, а само их раздвајају мера и време у апликацији начела" (Полемика Јована Ристића и српских конзервативаца 1877. године, Приредио Чедомир Попов, Београд 1997. стр. 202). Светоандрејским либералима је Ристић замерао „демократску тиранију”, сматрајући да њихова начела нису у складу са тадашњим степеном друштвеног развитка. С друге стране, одао им је признање за успостављање народног представништва као сталног органа власти. Ристићева политика „умереног корачања” сврстала је овог политичара у табор умереног либерализма. Без обзира на то што је био близак Илији Гарашанину, Ристић је на време схватио захтеве које је наметнуло ново доба „и за кога ради време” (Радовић, 2013, стр. 198). Као основ своје политике, Ристић је истицао правац „корак по корак”, док је Преображенску скупштину видео као основу за даљу изградњу тих начела. ${ }^{3}$ За разлику од светоандрејаца, чији је либерализам био „демократски обојен”, Ристић је имао одбојан став према упливу народних маса у политику, нагињући ка умереном либерализму, што га је „дуго година зближавало са конзервативном странком” (Бешлин, 2005, стр. 299). Био је присталица и творац умерених реформи које подстиче власт, а не маса. Једном приликом је кнезу Михаилу рекао:

„Ми смо на путу који ће реформе собом довести, па је мудрије да их сами дамо, но да нам оне буду силом отете; ако оне пођу одозго[,] биће плодне и спасоносне за земљу, пођу ли одоздо[,] оне могу прећи у неред и потрес, који не зна се где се може зауставити" (Симеуновић, 2003, стр. 230).

У својој политичкој каријери, Јован Ристић је зачетке Либералне странке везивао за 1848. годину, а његови истомишљеници су у неколико наврата узимали Светоандрејску скупштину 1858. године као време настанка Либералне странке. Ни једна ни друга година не могу се узети као године настанка Либералне странке, јер је 1848. године малобројна група интелектуалаца изнела своје либералне захте-

\footnotetext{
3 „Развитак људски тешко погађа средину, он је срећан, ако себи није затворио пут даљем кретању. У ову погрешку пре пада наглост, којој је тешко вратити се к средини, но разложност, којој остаје свагда слободан пут да к њој коракне, ако је заостала. Овај карактер умерености носи неоспорно рад Преображенске скупштине. Ако он у духу либерализма, и није задовољио захтевања свију ватрених патриота, он ни мало није затворио пут поправци и даљем развитку, који ће у толико јачи и позданији бити, у колико се брижљивије и смотреније примицао последњим оградама слободе" (Ристић, 1887, стр. 84).
} 
ве, а 1858. године се једна бројнија група залагала за остварење либералног и националног програма. Зачетке Либералне странке на челу са Јованом Ристићем налазимо за време Намесништва 1868-1872. године. Ову странку Ристић је у неколико наврата називао „умерено либерална или као што се радо звала, напредњачка". Да не би дошло до забуне, ваља напоменути да то није била савремена политичка странка, јер формално није имала ни програм, а ни организацију. Без обзира на то што није постојао писани програм, он се могао видети из више изјава Јована Ристића, нарочито када се имају у виду „Ристићеве замисли уређења Србије у његовом нацрту Уставу из 1869. године” (Јанковић, 1997, стр. 152-153).

Пре усвајања Устава из 1869. године, Ристић је имао свој нацрт Устава. По том нацрту, предвиђао се дводомни систем народног представништва: Народна скупштина и Земаљски савет. Народна скупштина се бирала на три године, с тим што је било прописано да сваке године испадне по једна трећина посланика чија су се места попуњавала накнадним изборима. Скупштина је бирала четири уместо шест кандидата за председништво, од којих је кнез једног постављао за председника, а једног за потпредседника. Земаљски савет, који је по нацрту бројао између 40 и 50 чланова, састојао се из вирилних и постављених чланова. Овај нацрт је омогућавао чиновницима право да се кандидују за посланике, ако су имали десет година државне службе и нису били војници. Устав из 1869. године, као што је речено, није усвојио дводомно, већ једнодомно народно представништво. Ристићев нацрт Устава није поднет Великој народној скупштини. Намесници су осетили да ће установа Земаљског савета поред Народне скупштине изазвати негодовање народних маса и зато су одустали од установе Земаљског савета, али су уместо ње предвидели кнежеве посланике, тј. обавезно именовање трећине посланика од стране кнеза. Устав из 1869. године забранио је чиновницима да се кандидују за народне посланике, док је по Ристићевом нацрту и чиновник могао бити народни посланик (Продановић, 1947, стр. 314-317).

Уставни нацрт Јована Ристића донекле може илустровати његов став према политичким реформама и политичким променама. Ристић је политичке реформе доживљавао као средство за очување власти, које треба примењивати само у крајњој нужди „без задирања у корените промене" (Јовановић, 1990б, стр. 83-84). Миливоје Петровић Блазнавац у разговору са Николом Крстићем је признао да је влада хтела да се игра с либерализмом. Либерализам владе је називао чистим „комедијашењем”. Блазнавац је Народну скупштину створену по Уставу из 1869. године називао „илузијом, институтом фантазије" (Крстић, 2006, стр. 165). Међутим, док се Блазнавац није много разумео у политички живот земље, јер је по струци био официр, 
Ристић је са својим умереним либерализмом постао политички вођа намесничког режима.

Оцењујући политичке ставове Блазнавца за време Намесништва, Никола Крстић је навео следеће: „Поставши намесник приста и он да се заводе слободне установе, али без слободе" (Крстић, 2006, стр. 198). Одржавао је контакте и са опозицијом у намери да се покаже као пријатељ и једних и других, тј. оних политичара који су били на власти за време кнеза Михаила и напредне школоване интелигенције, која је сматрала да је влада Намесништва и сувише конзервативна. Милан Пироћанац наводи да је младоконзервативним политичарима Блазнавац предлагао да уђу у будућу намесничку владу, јер је требало прекинути „са дотадашњим правцем и ослонити се на млађе и способне елементе”. Међутим, због упорног инсистирања Блазнавца да у Намесништво уђе Јован Ристић, а у Министарство унутрашњих дела Радивоје Милојковић, младоконзервативци су одбили позив Миливоја Блазнавца (Пироћанац, 1896, стр. 16). Међутим, у разговору са Бењамином Калајем, аустријским конзулом у Србији, Блазнавац је рекао да неће одустати од планираних реформи, иако ће због тога највероватниије бити критикован. За Јована Ристића је говорио да је сигуран да ће водити исту политику као и он и да га је због тога узео у Намесништво. ${ }^{4}$

Прву Владу за време Намесништва образовао је Ђорђе Д. Ценић 3. јула 1868. године. Осим председника, ова влада је имала три министара, при чему је сваки од њих држао по два ресора. Да је Влада била под јаким утицајем намесничког режима - сведочи чињеница „да је од 32 министарске седнице, колико је одржала ова влада, 31 одржана под председништвом намесника". Осим председника Владе и министра правде Ђорђа Ценића, који је био конзервативац, остали чланови владе (Радивоје Милојковић, Панта Јовановић, Јован Белимарковић) били су либерали или, боље речено, присталице Јована Ристића, осим донекле Белимарковића, који је сматран за светоандрејског либерала. Ово показује да су се многи либерали одрекли својих идеја како би се додворили намесничком режиму и заузели високе положаје у држави. Ристић намерно није попуњавало све министарске ресоре да би држао у неизвесности светоандрејске либерале и конзервативце, тј. да би му та непопуњена министарска места послужила као мамац за неке политичке актере до којих му је било

\footnotetext{
${ }^{4}$ Поставши намесник, Блазнавац је, за разлику од староконзервативаца, имао намеру да помоћу Јована Ристића придобије интелигенцију на страну Намесништва обећавајући увођење либералних реформи у Кнежевини Србији (Калај, 1976, стр. 57).
} 
стало. ${ }^{5}$ Тако је 6. октобра 1868 . у владу позвао либерала Димитрија Матића, који је заузео ресор Министарства просвете и црквених дела, док је Стојан Бошковић постао секретар Министарства иностраних послова. Убрзо након доношења Устава, образована је Влада Радивоја Милојковића 29. јула 1869. године. Поред Милојковића, остала су и три министра из претходног сазива, с тим што су извесно време министарске функције обављали и Јован Илић и Стојан Вељковић (Јанковић, 1997, стр. 154).

Без обзира на то што Либерална странка за време Намесништва није формално била организована као политичка странка, Јован Ристић је водио рачуна о одржавању партијске дисциплине, тј. слепе послушности својих присталица. ${ }^{6}$ На изборима за редовну Народну скупштину за период од 1871. до 1873. године главну улогу је одиграла полиција Радивоја Милојковића. Већину су добили либерали. Слободан Јовановић наводи да су „батине ударане без много ислеђивања и утврђивања кривице" за време министровања Радивоја Милојковића. „Прво га цепни па му онда тражи параграф!” (Јовановић, 19906, стр. 94).

Седамдесетих година 19. века, Ристић је несумњиво најјача политичка личност у Кнежевини Србији. Успео је да наметне своје идеје о јакој влади, тј. да министри што мање зависе од Скупштине (Љушић, 2010, стр. 97). За време Намесништва, Ристић је улагао велике напоре, користио разна средства да би образовао своју, односно владину, странку, која се називала либерална. Очување династије Обреновић послужило је намесницима као изговор да сузбију опозициони покрет у земљи и да придобију политичке противнике за своју либералну групацију. Иако није било велики заговорник идеја либерализма, Ристић је успео да окупи око себе велики број либерала, који су постали покорни чиновници. Тако је, на пример, Владимир Јовановић један од водећих идеолога либералног покрета у Србији постао покорни чиновник под командом Јована Ристића. Намесник

\footnotetext{
${ }^{5}$ Слободанка Стојичић наводи да је сасвим „извесно да су се позивали у владу само најпоузданији људи; уступци се нису чинили да би се владе комплетирале. Непопуњеност министарских места је давала наде виђенијим политичарима да ће бити постављени, а то им је диктирало бар за извесно време одрицање од идеја и програма које су пропагирали, а који се нису уклапали у нову уставност коју је Намесништво спроводило" (Стојичић, 1980, стр. 39).

${ }^{6}$ Јован Авакумовић у својим Мемоарима наводи да га је једном приликом изгрдио Јован Ристић, због тога што је приликом избора за Велику народну скупштину јуна 1869. године гласао за опозиционог посланика Милована Јанковића. „То се, рекао ми је, не слаже ни са вашим положајем секретара и повереника Радивојева, ни са дужношћу нашег пријатеља уопште. Према нашим пријатељима ви сте дужни показивати више оданости и нераздвојне везе, практичним радом и јавним поступцима" (Авакумовић, 2008, стр. 129).
} 
Ристић се веома добро сналазио у гломазној државној управи, јер је своју каријеру започео у полицијској струци. Политичка групација коју је Ристић окупио била је састављена од његових „личних поклоника и клијената". Дакле, државом је управљао пар намесника уз велику помоћ министра унутрашњих дела, док су сви остали били обични послушници (Јовановић, 2012, стр. 113-114).

Штампа је била изузетно погодно средство којим су се намесници користили да би учврстили своју власт и спречили деловање ојачале опозиције. У званичним или полузваничним новинама, Намесништво се хвалило и увеличавало своје успехе, док је опозиционе листове цензурисало, привремено обустављало или их гасило. Да је Ристић био против потпуне слободе штампе потврђује одбијање владе да прихвати један веома слободоуман предлог закона, који је објављен у Застави Светозара Милетића. Овим предлогом, под називом Основа закона о слободи пресе, било је предвиђено да се листови могу издавати без одобрења надлежне власти, као и укидање свих облика цензуре. Као што је речено, влада је одбила овај предлог, јер је био исувише либералан (Вулић, 2010, стр, 451). Неопходно је поменути и да је ректор Велике школе Јосиф Панчић био против доношења закона о штампи. Своје неслагање са доношењем закона о штампи образложио је на следећи начин:

„да је овај закон доста, а може бити за нас и превише либералан прво стога што смо ми доста млад и неискусан народ, који се у бујности својој лако на странпутице навести даје, а ово је за нас доста опасно, зато што немамо још потпуне самосталности, те морамо према иностранству у свачему смотрено да се владамо...” (АСАНУ, JP, VI/4, бр. 49).

У време Намесништва основан је посебан фонд за финансирање политичке пропаганде којим је руководио Јован Ристић. Финансирање пропаганде се обављало преко Министарства иностраних дела из фонда за „достојније заступање државних интереса”. Из овог фонда исплаћивање су дотације Јединству, финансиран је Прес-биро и исплаћивани разни други трошкови пропаганде (Бјелица, 1972, стр. 152). Непослушне чиновнике намесници су пензионисали, неке од њих предавали суду, док су својим присталицама обећавали, односно давали, места у државној служби. Јован Ристић је преко поверљивог Радивоја Милојковића успео да ојача утицај на полицијско чиновништво, иако непосредно није управљао полицијом. Министарство унутрашњих дела, на челу са Радивојем Милојковићем, било је од велике важности, јер је руководило унутрашњом управом земље, контролисало гласила и јавне иступе. Имајући у виду да је гласање по Уставу из 1869. године било јавно, полиција је држала у шаци и народне посланике, јер се директно мешала у изборни про- 
цес (Јовановић, 2012, стр. 112). Димитрије Маринковић у својим Успоменама наводи да је Намесништво пензионисало велики број чиновника у полицијској служби, а на њихова места постављало своје присталице. Ова појава је за последицу имала стварање партијског чиновништва, тј. чиновници су се опредељивали за владу или против ње. За време Намесништва створена је велика мрежа шпијуна, а све под изговором очувања династије Обреновић, после велике катастрофе у Кошутњаку. Блазнавац и Ристић, пошто су се већ истакли као спасиоци династије Обреновић, гледали су на све начине да придобију старе Обреновићевце нудећи им државне функције (на пример Стевчи Михаиловићу, кога нису узели у Намесништво, али су му дали фунцију стараоца имања малолетног кнеза Милана (Маринковић, 1939, стр. 211-215).

Милан С. Пироћанац је тврдио да му је један од намесника у великом заносу говорио: „Ми се не обазиремо: ни на способност ни на карактер у овој држави има места само за наше пријатеље”, док је његов министар унутрашњих послова Радивоје Милојковић, како наводи Пироћанац, „ову државничку мудрост преводио на овај разумљивији језик”: „Ко је с нама учинићемо све за њега што можемо. Ко је неутралан нема се од нас ничему надати. Ко је против нас, њега ћемо секиром по глави" (Пироћанац, 1895, стр. 6).

Политичка моћ намесника, а посебно Јована Ристића, почела је лагано да слаби доласком на власт кнеза Милана Обреновића 22. августа 1872. године. Истог дана када је постао пунолетан, изашла је прокламација у којој кнез Милан захваљује свом народу, народним посланицима, војсци, чиновницима, а посебно Намесништву. Намесништво је поднело кнезу Извештај о стању Србије од 12. јула 1868. до 22. августа 1872. године. Извештај је обухватао следеће одељке: о утврђивању унутрашњих односа после катастрофе из 1868. године, о унапређењу просвете; подизању народне економије, о правосуђу, о општим мерама за одржање здравља, живота и имовине од опасних људи и елемената, о одбрамбеној моћи земље; о предузетим активностима у спољној политици. Готово у свим областима друштвеног живота земље хвалио се рад владе Намесништва (Српске новине, бр. 95, 22. август 1872. године; Продановић, 1947, стр. 346).

Према бившим намесницима, нарочито према Ристићу, кнез Милан био је крајње неповерљив. Блазнавца није волео, јер је у њему видео свог супарника због његових претензија на престо, док је према Ристићу осећао одвратност (Јовановић, 1990б, стр. 159). Без обзира на то што је мрзео обојицу бивших намесника, кнез Милан је био толико интелигентан да их се није одмах ослободио, него је чекао погодну прилику за то, док се мало не учврсти на престолу (Јанковић, 1997, стр. 165). Убрзо по преузимању власти, кнез Милан се изјашњавао против Устава из 1869. године, који је донет за време 
његовог малолетства. Разлоге за ово противљење свакако треба тражити у његовој тежњи за апсолутном влашћу. Без обзира на то што су га намесници одржали на власти, он је био киван на њих, јер му нису књажевску власт сачували „у исто онако великом обиму у којем ју је имао кнез Михаило”. Кнез Милан је делио мишљење конзервативаца да је уставна промена из 1869. године велика политичка грешка. У њему је лагано почела да сазрева мисао да су конзервативци, а не намесници, прави стубови јаке владареве власти (Јовановић, 1990б, стр. 160). Да је кнез Милан у најмању руку био крајње неповерљив према намесницима сведочи и Стојан Новаковић. Он наводи да му је кнез Милан једном приликом рекао да је намеравао да ухапси намеснике (Миливоја Блазнавца, Јована Ристића и Јована Гавриловића) и да објави да по „уставним законима кнеза Михаила од 1861. године" Намесништво није имало право да промени Устав за време малолетства кнеза (Новаковић, 1908, стр. 2).

Прва скупштина сазвана након пунолетства кнеза Милана Обреновића састала се 6. октобра 1872. године у Крагујевцу. Скупштина је отворена престоном беседом 7. октобра 1872. године. Кнез је захвалио посланицима на дотадашњем раду и напоменуо да се само заједничким снагама могу решити сложени државни проблеми (Cpnске новине, бр. 113, 3. октобар 1872. године). Скупштина је одговорила адресом која је, у ствари, парафразирала беседу. Љубомир Каљевић је, заједно са петорицом посланика, предложио да адреса не би требало да садржи само одговор на садржај престоне беседе, већ да у њој треба да се истичу најзначајније жеље Народног представништва. Ова група посланика предложила је да се у адреси убудуће износе жеље народа да се поправи уређење општина, да се успоставе окружне скупштине које ће се, осим политичких, бавити и економским потребама локалних средина. Такође се тражило издавање царинских тарифа, закона о радњама и уређење администрације. Јован Бошковић је навео да у адреси треба да кажемо „шта нама треба”. Скупштина је затворена указом 6. новембра 1872. године.

Иако су Ристићеви либерали све до 3. новембра 1873. године задржали власт, апсолутна моћ Јована Ристића почела је да слаби. У одбору за адресу на почетку скупштинског заседања 1872. године појавила се опозиција влади (љ. Каљевић, К. Великић, А. Лукић, Ј. Бошковић, А. Николајевић и К. Стошић) (Протоколи Народне скуnштине држане у Крагујевиу 1872. године, Београд 1873, 25). Они су, као што је речено, тражили да се поправи Закон о устројству оnштина, да се изда закон о радњама, уреди администрација итд. За време своје владе Блазнавац се припремао да прекине са Ристићем и његовим либералима. Имао је план да се врати конзервативцима, с којима је био за време владавине кнеза Михаила Обреновића. Јован Ристић је навео да је „Блазнавац последњих дана свога живота при- 
уготовљавао за људе из Гарашанинове партије, а одвраћао од људи 1858. год." (Живановић, 1923, стр. 247). Међутим, то се није десило због изненадне смрти Миливоја Блазнавца 5. априла 1873. године. Кнез је био у дилеми кога да изабере за наследника Миливоја Петровића Блазнавца. Тада су постојале три политичке групације: стари либерали - Светоандрејски из 1858. године (Стевча Михаиловић, Јеврем Грујић, Милован Јанковић и др.), конзервативци (Гарашанин, Јован Мариновић и др.) и новолиберали, тј. Ристићеви либерали. Кнез није хтео светоандрејске либерале, јер су били сувише слободоумни, а неки од њих сматрани су републиканцима (Јанковић, Владимир Јовановић). Највише се колебао између конзервативаца и новолиберала. Више је волео конзервативце или барем коалицију између њих и новолиберала (Продановић, 1947, стр. 349). Међутим, до тога није дошло, па је кнез понудио Мариновићу да састави владу. Мариновић је то одбио.

Одбијање да састави владу Мариновић је правдао следећим разлозима: плашио се да не дође до опозиције његовој влади и сумњао је да може да побољша стање у земљи. ${ }^{7}$ Гарашанин је наговарао Мариновића да се прихвати да састави владу. Он је писао Мариновићу 15. априла 1873. године да је боље да се прихвати министарства, јер би се држава уредила према нашим приликама, а не да се из иностранства доносе форме којима се ништа не може поправити (Писма Илије Гарашанина Јовану Мариновићу од 4. јануара 1859. до 29. марта 1874. године, књ. 2. Приредио Стеван Ловчевић. Београд 1931, стр. 321). У кабинету који је Ристић образовао 14. априла 1873. године није било ни Радивоја Милојковића, а ни Јована Белимарковића. Оваквим саставом Владе, који му је такорећи наметнуо кнез Милан Обреновић, Ристић није био задовољан. Допустио је да се кнез меша у састав Владе, што је за последицу имало јачање кнежеве жеље за личним режимом (Продановић, 1947, стр. 350). Ристићеви либерали су стално истицали да се њихова идеологија није променила после 1872. године, ни када су били на власти, ни у опозицији. Непрестано су потенцирали да су наводно први и главни представници либералних, али увек умерених, реформи у Србији. ${ }^{8}$ Међутим,

7 У писму Јовану Мариновићу поводом његовог одбијања да састави владу, Гарашанин је написао: „Истина је оно што си књазу казао да би опозиције било твом Министарству, но кажи ти мени хоће ли књаз бити у стању да створи једно Министарство, које неће опозиције имати; па лакше је на сваки начин трпети опозицију Министарству, кад је оно из најбољих људи састављено него из свакојаких" (Писма Илије Гарашанина Јовану Мариновићу од 4. јануара 1859. до 29. марта 1874. године, къ. 2. Приредио Стеван Ловчевић. Београд 1931, стр. 319).

8 У Народној скупштини из 1879/1880. године, Јован Ристић је по ко зна који пут истицао предности вођења умерене политике. „Крајности нису никада путеви слободе, умереност је пут, који слободу води, умереност је штит, који слобо- 
опозиција је била крајње неповерљива према свим либералним владама, а нарочито је нападала Јована Ристића. Због његових карактерних особина, а посебно због његовог владалачког држања, био је на мети тешких напада од стране опозиције. Влада Јована Ристића није дочекала скупштину сазвану за 27. новембар 1873. године. Кнез Милан је изнудио оставку Владе Јована Ристића 3. новембра 1873. године. У јавности је оставка Владе представљена поремећеним здрављем Јована Ристића (Продановић, 1947, стр. 351). Кнез Милан је упутио ласкаво писмо Ристићу у коме наводно жали што је био принуђен да га отпусти због слабог здравља „захваљује му на патриотским услугама и изјављује надаље да ће му свагда саветом бити у помоћи, кад год га буде за савет питао" (Крстић, 2006, стр. 208). Мотиве Ристићевог пада с власти треба тражити у његовој властољубивости коју нису могли да поднесу не само његови министри него ни кнез Милан Обреновић. Ристић је са министрима поступао као са млађим чиновницима; они су му редовно реферисали о свом раду, а он им је издавао упутства (Јовановић, 1990б, стр. 166). Ристићеве методе застрашивања и поткупљивања људи државном службом најбоље се огледају на примеру Владимира Јовановића. Уморан од сталних прогона због својих либералних схватања, Јовановић је одлучио да затражи државну службу. Добио је место секретара у Министарству унутрашњих дела. Ристић се на тај начин ослободио опасног политичког противника. ${ }^{9}$ Ристић није имао шта да тражи у ситуацији када министри које је поставио нису могли да поднесу његова понижавања, а кнез Милан његову надменост и охолост. Поднео је оставку, као што је наведено, 3. новембра 1873. године (Јовановић, 1990б, стр. 166-168).

ду чува. Ја нисам никада у моме веку налазио за добро да будем друг крајности и бујности, ишао сам свагда средњим путем, и мислим да сам слободи ове земље привредио више но они, који су ишли путем крајности" (Стенографске белешке о седницама Народне скупштине која је држана у Нишу 1879. и 1880, II део, Београд 1880, стр. 1472).

${ }^{9}$ Ристић је у писму Филипу Христићу то овако објаснио: „Пређе је он (Владимир Јовановић) независан човек па нам је правио често незгода, а сад дошавши у одношаје службене мораће стајати под дисциплином чиновничком, ако не жели да изгуди свој комад. Он се на то и обавезао. Његов радикализам неће ни мало опасан бити у поштанској администрацији, у којој је службу добио; напротив, он је и ту себи руке везао државном службом" (Писма Јована Ристића Филипу Христићу од 1870. до 1873. и од 1877. до 1880. године, Зборник за историју, језик српског народа, књ. 20, Београд 1931, стр. 234). 


\section{ЗАКљУЧАК}

За време малолетства кнеза Милана Обреновића (1868-1872), намеснички режим успео је да придобије већину либерала и да им повери неке задатке везане за доношење новог устава. Обећавајући увођење одређених реформи у земљу, Ристић је вештим маневром успео да умеренији део либерала привуче на своју страну. Иако су се прве партијске клице појавиле за време Светоандрејске скупштине 1858. године, када су се коначно искристалисале две политичке групације - конзервативци и либерали, тек са Намесничким режимом отпочео је прави политичко-партијски живот у Србији. За време Светоандрејске скупштине 1858. године, Ристић је заступао умерени либерализам, јер је сматрао да је полицијско-бирократски режим кнеза Михаила Обреновића постао толико непопуларан да га само одређене реформе могу спасити. Неслагање са постојећом политиком режима кнеза Михаила Ристићу је обезбедило популарност међу либералном интелигенцијом, без обзира на то што га убеђени либерали Јеврем Грујић, Владимир Јовановић и Милован Јанковић никада нису доживљавали као свог истомишљеника. Када је у питању Либерална странка, ваља указати на разлику између либерала са Светоандрејске скупштине и оних који су се за време Намесништва окупили под вођством Јована Ристића. Светоандрејски либерали нису представљали основу касније основане Либералне странке, на челу са Ристићем, чије зачетке налазимо тек за време Намесништва 1868 1872. године.

Захвалница: Рад је настао као резултат истраживања на пројекту Министарства просвете, науке и технолошког развоја Републике Србије Модернизација западног Балкана (бр. 177009).

\section{НЕОБЈАВљЕНИ ИЗВОРИ}

Архив Српске академије наука и уметности - лични фонд Јована Ристића (ACAHY, JP, VI/4, br.48-49) [Archives of the Serbian Academy of Sciences and Arts, Personal fund of Jovan Ristic, $\mathrm{N}_{\mathrm{o}}$.48-49].

Архив Србије - лични фонд Владимира Љотића (АС; Вљ-3) [Archives of Serbia, Personal fund of Vladimir Ljotic, No.3].

\section{ОБЈАВЉЕНИ ИЗВОРИ}

Авакумовић, Јован (2008). Мемоари. [Memoirs.]. Приредио Слободан Турлаков. Сремски Карловци - Нови Сад: Издавачка књижарница Зорана Стојановића

Бењамин Калај (1976). Дневник 1868-1875. [Diary 1868-1875.]. Приредио Андрија Раденић. Београд - Нови Сад: Историјски институт

Вулетић, Александра, Трговчевић, Љубинка (2003). Аутобиографске белешке Радивоја Милојковића, [Autobiographical notes of Radivoje Milojkovicy]: Мешовита грађа, књ. XXI. Београд: Историјски институт. 
Крстић, Никола (2006). Дневник. Јавни живот, књ. 2. [Diary. Public life, book 2.]. Приредио Милош Јагодић. Београд: Завод за уџбенике и наставна средства.

Маринковић, Димитрије (1939). Успомене и доживљаји (1846-1869). [Meтогіes and experiences (1846-1869)]. Приредио Драгослав Страњаковић. Београд: Задужбина Јелисавете и Милана Јанковића

Новаковић, Стојан (1908). Бугарско-српски рат и оновремене кризе 1885-1886. Мемоарски листићи, [Bulgarian-Serbian war and the crisis at the time 1885-1886. Memoirs' lists.], у: Годишњица Никола Чупића, књ. 27. Београд: Државна штампарија

Петровић, Аврам (1988). Успомене. [Memories.]. Приредила Латинка Перовић. Горњи Милановац. Дечије новине.

Писма Илије Гарашанина Јовану Мариновићу од 4. јануара 1859. до 29. марта 1874. године, къ. 2. [The letters of Ilija Garasanin to Jovan Marinkovic from $4^{\text {th }}$ January 1859 to $29^{\text {th }}$ March 1874, book 2.]. Приредио Стеван Ловчевић, Београд 1931

Писма Јована Ристића Филипу Христићу од 1870. до 1873. и од 1877. до 1880. године, [The letters of Jovan Ristic to Filip Hristic from 1870 to 1873 and from 1877 to 1880]. Зборник за историју, језик српског народа, књ. 20. Београд 1931.

Полемика Јована Ристића и српских конзервативаиа 1877. године, [The debate of Jovan Ristic and Serbian conservatives in 1877.]. Приредио Чедомир Попов, Београд 1997.

Протоколи Народне скупштине држане у Крагујевиу 1872. године, [The protocols of National assembly held in Kragujevac in 1872]. Београд 1873.

Стенографске белешке о седницама Народне скупитине која је држана у Нишу 1879. и 1880, књ. 2. [ Stenographic notes about the meetings of National assembly held in Nis in 1879 and 1880, book 2]. Београд 1880.

Штампа: Српске новине

\section{ЛИТЕРАТУРА}

Бешлин, Бранко (2005). Европски утищаји на српски либерализам у ХІХ веку. [European influences on Serbian liberalism in XIX century]. Сремски Карловци - Нови Сад: издавачка књижарница Зорана Стојановића.

Бјелица, Михаило (1972). Политичка штампа у Србии 1834-1872. године. [Political news in Serbia 1834-1872]. Београд: Југословенски институт за новинарство

Вулић, Т. (2010). Прописи о штампи у ХІХ веку, у: Крагујеваи у другој половини деветнаестог века. [Regulations on the Serbian Press in the 19th century, Kragujevac in the second half of the nineteenth century]. Крагујевац: Историјски архив Шумадије.

Живановић, Живан (1923). Политичка историја Србије у другој половини 19. века, књ. 1. [Political history of Serbia in the second half of $19^{\text {th }}$ century, book 1]. Београд: Геца Кон

Живановић, Живан (1924). Политичка историја Србије у другој половини 19. века, књ. 3. [Political history of Serbia in the second half of $19^{\text {th }}$ century, book 3.]. Београд: Геца Кон.

Јанковић, Драгослав (1997). Рађање парламентарне домократије. О политичким странкама у Србији XIX века. [The birth of parliamentary democracy. About political parties in Serbia in XIX century]. Београд: Правни факултет. 
Јовановић, Слободан (1934). Влада Милана Обреновића, књ. 1. [The government of Milan Obrenovic, book 1.]. Београд: Геца Кон.

Јовановић, Слободан (1990a), Политичке и правне расправе, I-III. [Political and legislative debates, I-III.]. Београд: БИГЗ.

Јовановић, Слободан (1990б). Влада Милана Обреновића, књ. 1. [The government of Milan Obrenovic, book 1.]. Београд: БИГЗ.

Јовановић, Владимир (2012). Тајна полиција Кнежевине Србије. [The secret coalition of the Principality of Serbia]. Београд: Историјски институт.

Леовац, Данко (2015). Србија и Русија. За време друге владавине кнеза Михаила (1860-1868). [Serbia and Russia. During the second reign of prince Mihailo (1860-1868.)]. Београд: Службени гласник.

Љушић, Радош (2008). Српска државност 19. века. [Serbian statehood of $19^{\text {th }}$ century]. Београд: Српска књижевна задруга.

Љушић, Радош (2010). Владе у Кнежевини и Краљевини Србији (1805-1918.). [The governments in the Principality and in the Kingdom of Serbia (18051918.)]. у: Српске студије, књ. 1. Београд: Филозофски факултет.

Пироћанц, Милан (1895). Кнез Михаило и заједничка радња Балканских народа. [Prince Mihailo and mutual work of Balkan peoples]. Београд: Државна штампарија Краљевине Србије.

Пироћанац, Милан (1896). Наша завршна реч (поводом дискусија о политищи кнеза Михаила). [Our final word (regarding the discussions about politics of prince Mihailo)]. Београд: Парна радикална штампарија.

Продановић, Јаша (1947). Историја политичких странака и струја у Србији, къ. 1. [The history of political parties and streams in Serbia, book 1.]. Београд: Просвета.

Радовић, Данијел (2013). Јован Ристић и либерали у Кнежевини Србији (18581868) - Од супарника до предводника. [Jovan Ristic and the Liberals in the Kingdom of Serbia (1858-1868) - from rivals to leaders]. у: Српске студије, књ. 4. Београд: Центар за српске студије, Филозофски факултет.

Рајић, Сузана (1998-1999). „Српска независност” орган Народне либералне странке. [Serbian independence - an organ of National liberal party]. y: Годишњак града Београда, књ. XLV-XLVI. Београд: Музеј града Београда.

Рајић, Сузана (2015). Спољна политика Србије. Између очекивања и реалности 1868-1878. [Foreign policy of Serbia. Among the expectations and reality 1868-1878]. Београд: Српска књижевна задруга.

Ристић, Јован (1887). Спољашњи одношаји у Србији новијега времена II (18601868) [Foreign affairs in Serbia of new times II. (1860-1868)]. Београд.

Симеуновић, Драган (2003). Нововековне политичке идеје у Срба, къ. 1. [Newage political ideas in Serbs, book 1.]. Београд: Иниститут за политичке студије и Правни факултет Бања Лука.

Стојичић, Слободанка, Уставни развитак Србије 1868-1888. године. [Constitutional development of Serbia 1868-1888.]. Лесковац: Народни музеј.

Чубриловић, Васа (1958). Историја политичке мисли у Србији ХІХ века. [The history of political thinking in Serbia in XIX century]. Београд: Просвета. 


\title{
THE GATHERING OF THE LIBERALS UNDER THE LEADERSHIP OF JOVAN RISTIC FROM 1868 TO 1873
}

\author{
Miroslav Pešić \\ University of Niš, Faculty of Philosophy, Niš, Serbia
}

\begin{abstract}
Summary
During the juvenile age of prince Milan Obrenovic (1868-1872), the Governorship regime managed to win most of the liberals and to entrust them certain missions related to the adoption of the new Constitution. By promising to introduce certain reforms in the country, Ristic managed to attract the more moderate part of the liberals to his side with a skillful maneuver. Although the first germs of parties appeared during the St. Andrea's assembly in 1858, when two political groups, conservatives and liberals, finally crystallized, it was only with the Governorship regime that the true political-party life in Serbia started. During the St. Andrea's assembly in 1858, Ristic supported a more moderate liberalism because he considered that the police-bureaucratic regime of Prince Mihailo Obrenovic became so unpopular that only certain reforms could save it. The disagreement with the existing politics of Prince Mihailo's regime secured Ristic the popularity among liberal intelligence, regardless of the fact that the convinced liberals such as Jevrem Grujic, Vladimir Jovanovic and Milovan Jankovic never saw him as a likeminded person. When it comes to the Liberal party, a difference between liberals from St. Andrea's assembly and those who gathered under the leadership of Jovan Ristic during the Governorship should be pointed out. St. Andrea's liberals did not represent the base of the later founded Liberal party led by Ristic whose beginnings we find during the Governorship from 1868 to 1872.
\end{abstract}

